\title{
Reversible visual memory in transient splenial lesion
}

Figure Diffusion-weighted MRI exhibits increased signal change in splenium (A), the initial signal resolved on follow-up MRI (B), and performance of Rey-Osterrieth complex figure test also improved

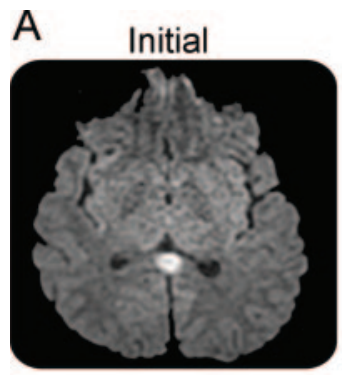

\section{$B$ Two weeks later}

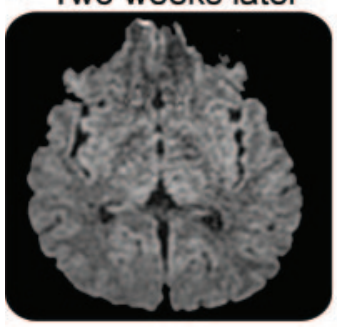

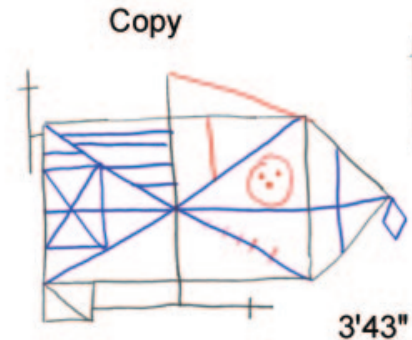

3'43"
Immediate recall

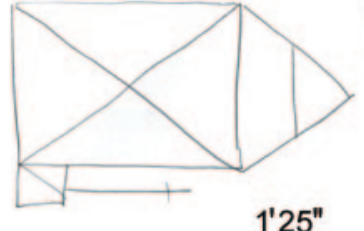

$1^{\prime} 25^{\prime \prime}$
Delayed recall

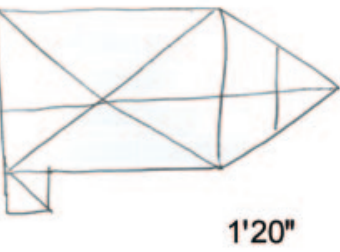

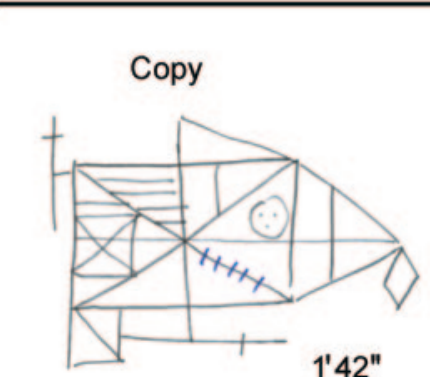

Immediate recall

Delayed recall
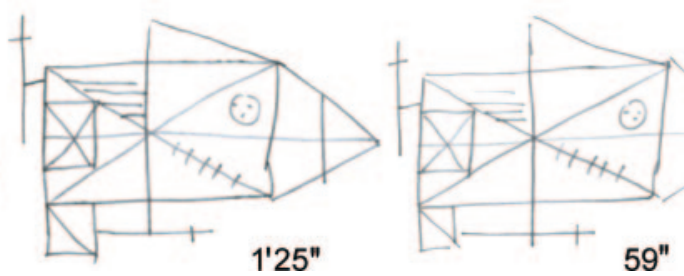

$59^{\prime \prime}$

A 19-year-old man presented with vertigo and headache. Diffusion MRI showed an increased signal on the center of the splenium. Neuropsychological assessment demonstrated impairment on immediate and delayed recall of the Rey-Osterrieth complex figure test. His visual memory had improved by the time the splenial lesion disappeared on follow-up MRI (figure).

Although transient splenial lesions are commonly seen on diffusion-weighted imaging related with various conditions, the exact pathophysiology and its significance are not clear. ${ }^{1}$ Visual memory performance in our patient supports that splenium has an important role for integration of visual information through the temporal, parietal, and occipital cortical regions. ${ }^{2}$

Seong-Hae Jeong, MD, Ji Hee Lee, MD, and Ae Young Lee, MD, PhD, Daejeon, Korea

Disclosure: The authors report no disclosures.

Address correspondence and reprint requests to Dr. Ae Young Lee, Department of Neurology, Chungnam National University Hospital 640, Daesa-dong, Joong-ku, Daejeon, 301-721, Republic of Korea; aelee@cnu.ac.kr

1. Doherty MJ, Jayadev S, Watson NF, Konchada RS, Hallam DK. Clinical implications of splenium magnetic resonance imaging signal changes. Arch Neurol 2005;62:433-437.

2. Hofer $S$, Frahm J. Topography of the human corpus callosum revisited: comprehensive fiber tractography using diffusion tensor magnetic resonance imaging. NeuroImage 2006;32:989-994. 


\title{
Neurology
}

\author{
Reversible visual memory in transient splenial lesion \\ Seong-Hae Jeong, Ji Hee Lee and Ae Young Lee \\ Neurology 2009;73;647 \\ DOI 10.1212/WNL.0b013e3181b38a16
}

This information is current as of August 24, 2009

\section{Updated Information \& Services}

References

Citations

Subspecialty Collections

Permissions \& Licensing

Reprints including high resolution figures, can be found at: http://n.neurology.org/content/73/8/647.full

This article cites 2 articles, 0 of which you can access for free at: http://n.neurology.org/content/73/8/647.full\#ref-list-1

This article has been cited by 1 HighWire-hosted articles: http://n.neurology.org/content/73/8/647.full\#\#otherarticles

This article, along with others on similar topics, appears in the following collection(s):

All Cognitive Disorders/Dementia

http://n.neurology.org/cgi/collection/all_cognitive_disorders_dementia Clinical neurology examination

http://n.neurology.org/cgi/collection/clinical_neurology_examination

MRI

http://n.neurology.org/cgi/collection/mri

Visual processing

http://n.neurology.org/cgi/collection/visual_processing

Information about reproducing this article in parts (figures,tables) or in its entirety can be found online at:

http://www.neurology.org/about/about_the_journal\#permissions

Information about ordering reprints can be found online:

http://n.neurology.org/subscribers/advertise

Neurology ${ }^{\circledR}$ is the official journal of the American Academy of Neurology. Published continuously since 1951, it is now a weekly with 48 issues per year. Copyright . All rights reserved. Print ISSN: 0028-3878. Online ISSN: 1526-632X.

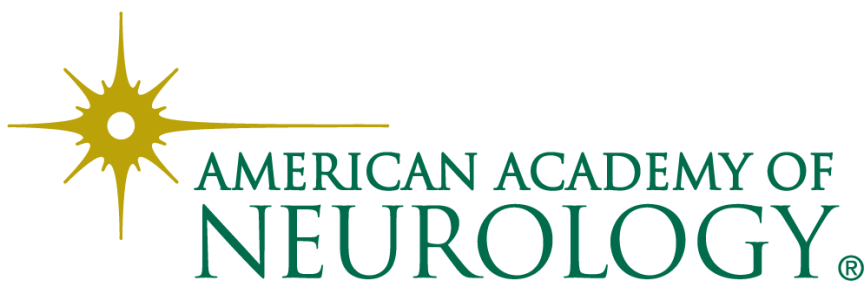

